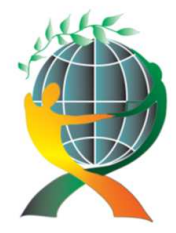

\author{
(online) = ISSN $2285-3642$ \\ ISSN-L = $2285-3642$ \\ Journal of Economic Development, Environment and People \\ Volume 7, Issue 2, 2018
}

URL: http://jedep.spiruharet.ro

e-mail: office jedep@spiruharet.ro

\title{
Analysis of Tidung Island Tourist Perceptions and Preferences Using Importance Performance Analysis Method
}

\author{
Muhamad Syahiddin ${ }^{1}$, Dhian Tyas Untari ${ }^{1}$ and Paryono ${ }^{1}$ \\ ${ }^{1}$ Universitas Indraprasta PGRI, South Jakarta, Indonesia
}

\begin{abstract}
The purpose of this research is: A) mapping the perception of tourists on Tidung Island tourism, b) mapping the preferences of tourists on Tidung Island tour. Primary data were obtained from questionnaires distributed to Jakarta citizen (as potential tourists) and tourists (as existing customers), a total of 200 respondents. Aspects in the study include: product, promotion, transportation, price and service. The Important Performance Analysis (IPA) method is used to analyze the data. The results showed that: Cleanliness and appearance of the site is still considered less attractive by the public, in general. There is a GAP between the perceptions of the preference of potential tourists and existing tourists. So, to maintain the sustainability of tourism on the Tidung Island, then the cleanliness and appearance of tourist sites should be improved by administrators of Tidung Island.
\end{abstract}

Keywords: perception, preference, Tidung Island, Importance Performance Analysis (IPA)

\section{JEL Codes: A13}

How to cite: SYAHIDDIN, M., UNTARI, D., \& PARYONO, P. (2018). Analysis of Tidung Island Tourist Perceptions and Preferences Using Importance Performance Analysis Method. Journal of Economic Development, Environment and People, 7(2), 22-29. doi:http://dx.doi.org/10.26458/jedep.v7i2.580

\section{Introduction}

The tourism sector has an economic multiplier effect for local governments through increasing the original regional income (Vanhove, 2005) and community economy through the expansion of employment opportunities and increasing the quantity of income (Mathew and Sreejesh, 2017). In Indonesia, the tourism sector is a major contributor of foreign exchange. Overall, the tourism sector became the No. 5 contributor in 2008, No. 4 in 2009 and No. 5 in 2010 (Untari, 2016; Siregar, 2004). The challenge in tourist development is to maximize the role of every stakeholder to collaborate (Lyon et al, 2017).

Tourism development priorities are set in 10 (ten) national tourism destinations, namely DKI Jakarta, West Java, Central Java and Jogyakarta, East Java, Bali, North Sumatra, West Sumatra, North Sulawesi and South Sulawesi, by the Directorate General of Tourism, in 1999. Determination of government Policies in tourism development are based on two main ideas: 1) Availability of infrastructure and the amount of tourism potential in the area concerned, 2). The principle of "equitable development", so that tourism development can be implemented simultaneously without ignoring the potential sources in each region (Untari et al, 2017). 


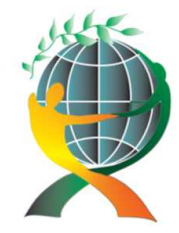

\author{
(online) = ISSN $2285-3642$ \\ ISSN-L = $2285-3642$ \\ Journal of Economic Development, Environment and People \\ Volume 7, Issue 2, 2018 \\ URL: http://jedep.spiruharet.ro \\ e-mail: office jedep@spiruharet.ro
}

Jakarta has a variety of tourist attractions and Jakarta is one of many regions in Indonesia that has a very high compacity of community social interaction (Untari et al, 2017) and as a macro impact, Jakarta is has the largest contribution to Indonesian economic growth (Sumaryoto, 2016). Jakarta has a good image as a rural tourism and image of a destination give a significant impact for tourist motivation (Martens and Reiser, 2017). It can be seen from the large number of tourist visits to Jakarta, actually foreign tourists visiting the capital city through 3 entrances. In November 2013, it increased by 3.74 percent, compared to the previous month's visit, or 198,066 visits in October 2013 to 205,468 visits in November 2013. (BPS DKI Jakarta, 2015). One of the most interesting tourist destinations in Jakarta is Tidung Island, which is administratively located in the Thousand Islands Administration District. As the implementation of decentralization policy through Statute Number 23 of 2004, the authority of tourism policy is the authority of local government. The implementation of regional autonomy provides logical consequences for local governments to take care of their own households and have full responsibility for improving the prosperity of their people through tourism development activities (Choi et al. 2018). Tourism sector becomes one of the leading sectors in the economic development direction of Thousand Islands Regency. Through the development of tourism sector is expected to maximize the existing tourism potential and can move towards independence, and all depends on destination management of Tidung Island (Sari, 2009; Purnama, 2008; Aprilia, 2008)

Based on these backgrounds, there are several facts, namely:

1) DKI Jakarta is the leading destination of Indonesia,

2) high potential so that Tidung Island can be promoted to Jakarta's flagship tourist sites, and

3) it needs to map the perceptions and preferences of travelers to float further business strategy. Thus, the problem to be solved in this research is how people's perception and preferences influences on tourism in Island Tidung.

Based on several aspects and problems to be solved in this research, the purpose of research is:

A) to identify and map the perception of tourists,

b) to identify and map the preferences of tourists to travel on the Island of Tidung.

\title{
2. Method
}

Primary data were obtained from questionnaires distributed to Jakarta citizen (as potential tourists) and tourists (as existing customers), a total of 200 respondents. The method of sampling is used to determine the respondents, this being due the fact that there is no accurate data on the number and profile of the tourist. Descriptive method used for data processing it was statistic descriptive. Aspects of perception in the study include: Product aspect, promotion aspect, transportation aspect, price aspect and service aspect. Whereas, in the preference aspect of coverage; aspects of product information, aspects of existing products, promotion aspects, transportation aspects, price aspects and service aspects. Importance Performance Analysis (IPA) is used in analyzing data to compare expectations and importance levels in tourist perceptions, in graphic form.

The first step in the method of Importance Performance Analysis (IPA) is to determine the level of conformity between the attributes studied through the comparison of perception scores with the preference score. The formula of the suitability level used is (Santoso; 2011 Dalam Anggraini et al; 2013): 


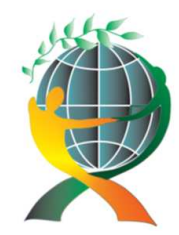

$T k i=\frac{\mathrm{Xi}}{\mathrm{Yi}} \cdot 100 \%$

Description :

Tki = Level of conformity

$\mathrm{Xi} \quad=$ Perception rating score

$\mathrm{Yi} \quad=$ Preference rating score (online) $=$ ISSN $2285-3642$

ISSN-L = $2285-3642$

Journal of Economic Development, Environment and People

Volume 7, Issue 2, 2018

URL: http://jedep.spiruharet.ro

e-mail: office jedep@spiruharet.ro

Furthermore, the average calculation of all attribute level of perception $(\mathrm{X})$ and preference $(\mathrm{Y})$ becomes the limit in Cartesian diagram, by the formula,

$$
C-\text { line } X=\frac{\Sigma X}{\mathrm{k}} \quad C-\text { line } Y=\frac{\sum Y}{\mathrm{k}}
$$

Description;

$\mathrm{C}$-Line $\mathrm{X}$ atau $\mathrm{C}$-Line $\mathrm{Y}=$ Average perceptual rate score $(\mathrm{X})$ or preference $(\mathrm{Y})$

atau $=$ Average perception rate $(X)$ or preference $(Y)$

$\mathrm{K}=$ Number of attributes

\section{Result and Dsiscussion}

\subsection{Tourism Profile on Tidung Island}

Tidung Island is one of the villages in the district of Thousand Island, Jakarta, Indonesia. The island was developed into marine tourism destinations such as diving as well as research on coral reefs. Tidung Island is an Island of Islands in the Thousand Islands and is particularly attractive for local and foreign tourists. Tidung is actually a group of two islands: Big Tidung and Small Tidung. There is a bridge that divides the sea that connects the two islands. As a marine tourism object, Tidung Island began to be known by the community since 2010, because of the beauty of the coast and charm of Jembatan Cinta. Since then, Tidung Island began to be used as a marine tourism alternative to Pramuka Island and Pari Island, in the Thousand Islands. And tourists interest to Tidung Island is increasing every day. Tidung Island can be reached from North Jakarta either from the port of Muara Angke or Marina Ancol port.

Tidung Island has very interesting tourist sites, beautiful coastal landscapes and a charming 'love bridge' as a liaison between the Big Island and the Small Island. In addition, connoisseurs of historical tourism can also be found on the island of Tidung, through the Tombs of the Kingdom Tidung royalty, located in Kuala Malinau, East Kalimantan, named Raja Pandita. According to local community legends, it is assumed that King Pandita was ousted by the Dutch colonial government of the island. That's where the name Tidung Island comes from. In 2011, occurs the removal of the tomb of King Pandita, originally located at the west end of the current burial area. In addition to historical tours, underwater tourism is also a special attraction for visitors. Underwater charm around the island Tidung could also be a reference for tourists who are looking for marine tourism activities such as diving, snorkeling and fishing. The dynamics of life of Tidung Island residents, as a marine population, becomes a special tourist attraction. Various types of fish \& seafood could be commodities with high potential recovery by making special offerings to tourists. 


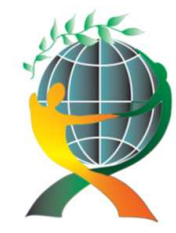

\author{
(online) $=$ ISSN $2285-3642$ \\ ISSN-L = $2285-3642$ \\ Journal of Economic Development, Environment and People \\ Volume 7, Issue 2, 2018
}

URL: http://jedep.spiruharet.ro

e-mail: office jedep@spiruharet.ro

\title{
3.2. Profile of Respondents
}

Based on the results of questionnaires spread on the potential tourists and existing tourists, were obtained the following data (Table 1):

Table 1. Profile of Respondents

\begin{tabular}{|l|l|l|}
\hline Component & Potential Tourist & Existing Tourist \\
\hline Gender & 52 Female & 63 Female \\
& 48 Male & 37 Male \\
\hline Educational Background & 11 High School & 21 High School \\
& 64 University graduates & 61 University graduates \\
& 25 Post-graduates & 18 Post-graduates \\
\hline Activity & 79 Employee & 55 Employees \\
& 12 Public Servant & 29 Public Servant \\
& 5 Entrepreneur & 16 Entrepreneur \\
& 4 Jobless & 1 Jobless \\
\hline Income & $26,<3.000 .000$ & $24,<3.000 .000$ \\
& $59,3.000 .001-5.000 .000$ & $66,3.000 .001-5.000 .000$ \\
& $15>5.000 .000$ & $10,>5.000 .000$ \\
\hline
\end{tabular}

Source: Primary data, 2017

\subsection{Finding}

The perception and preference of potential clients are presented below:

Table 2. Perception and Preference of Potential Clients - Source; Primary data, 2017

\begin{tabular}{|c|c|c|c|c|c|}
\hline Variable & Indicator & Perception & Preference & GAP (Pe-Pr) & Tki \\
\hline \multirow[t]{4}{*}{ Product } & Quality of Tourist Site & 4 & 3 & 1 & 1,33 \\
\hline & Diversity of Attractions & 4 & 5 & -1 & 0,80 \\
\hline & Cleanliness & 3 & 3 & 0 & 1,00 \\
\hline & Queue Method & 3 & 1 & 2 & 3,00 \\
\hline \multirow[t]{2}{*}{ Promotion } & Media Quality & 5 & 2 & 3 & 2,50 \\
\hline & $\begin{array}{l}\text { Frequency of } \\
\text { promotion }\end{array}$ & 4 & 2 & 2 & 2,00 \\
\hline \multirow[t]{3}{*}{ Transportation } & Conveyance Quality & 4 & 3 & 1 & 1,33 \\
\hline & Frequency & 3 & 3 & 0 & 1,00 \\
\hline & Length of Travel & 3 & 2 & 1 & 1,50 \\
\hline \multirow[t]{4}{*}{ Price } & Food Prices & 3 & 2 & 1 & 1,50 \\
\hline & Accommodation Price & 3 & 2 & 1 & 1,50 \\
\hline & Mode Ticket Price & 4 & 3 & 1 & 1,33 \\
\hline & Rental Price & 4 & 4 & 0 & 1,00 \\
\hline \multirow[t]{2}{*}{ Service } & HR Quality & 2 & 3 & -1 & 0,67 \\
\hline & Quality Amenities & 3 & 3 & 0 & 1,00 \\
\hline & C-Line & 3,47 & 2,73 & 0,73 & 1,43 \\
\hline
\end{tabular}




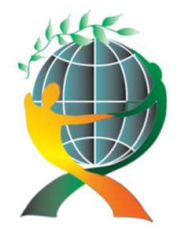

\author{
(online) $=$ ISSN $2285-3642$ \\ ISSN-L = $2285-3642$ \\ Journal of Economic Development, Environment and People \\ Volume 7, Issue 2, 2018 \\ URL: $\underline{\text { http://jedep.spiruharet.ro }}$ \\ e-mail: office jedep@spiruharet.ro
}

Table 2 presents the result of questionnaires tabulation data about tourists' perceptions and preferences on tourism in Island Tidung; Product aspect, promotion aspect, transportation aspect, price aspect and service aspect.

The above table shows that the potential tourist perception towards tourism development is quite high $(3,4)$, but Tidung Island tourism management performance is still considered to be less $(2,73)$, so it cannot motivate the potential tourists to visit Tidung Island. The next fact is, tourists' perceptions and preferences are almost the same (0.67) and the potential tourist perception index is still higher than their preference for tourism in Island Tidung (1.36). Such data can be interpreted in the form of IPA Potential Client chart, as follows (Fig. 2):

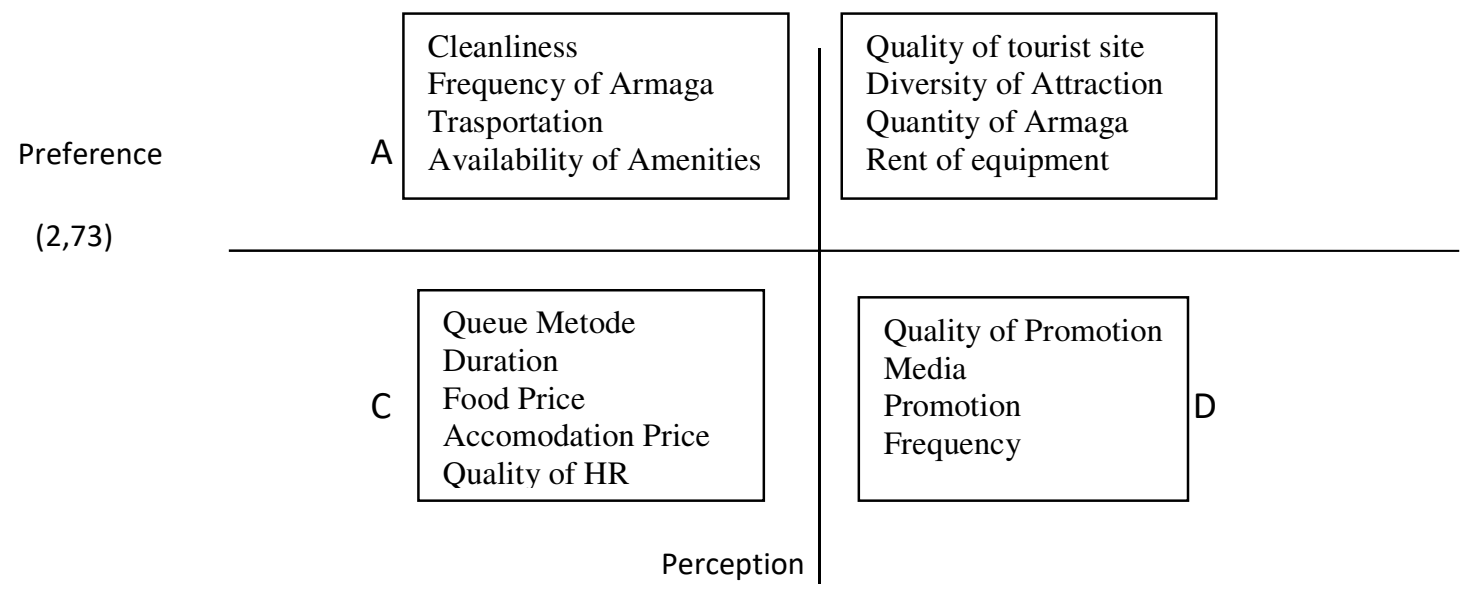

$(3,47)$

Source: Primary Data, 2017

Fig 2. IPA Potential Tourists

Thus, it appears that the indicators of Quality of Tourist Site, Diversity of Attraction, Armaga Quality, Rental Price is considered as a good enough indicator by the public, generally. The four indicators are perceived as an indicator that can affect people to want to visit Tidung Island and considered Tidung Island tourism has met these four indicators. While the indicators of Cleanliness Site Tours, Frequency fleet, Mode Ticket Price, Quality Amenities considered as an important indicator for a tourist, but the community considers the four indicators are not maximized in Tidung Island tour. In the indicator of Queue Method, Length of Travel, Food Price, Accommodation Price, Quality of Human Resource is considered not very important by the community. This is because people are familiar with Tidung Island as a community-based tourist destination so that people tend to tolerate the limited human resources in Tidung Island. The development of tour packages that have brought together the package price makes the price of food and lodging is not an indicator that is too important for Tidung Island tour. And the indicator of Media Quality and Frequency of Promotion is considered important for the community but, in fact, people rarely see the 


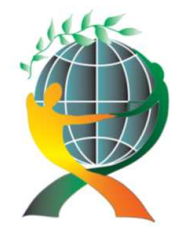

\author{
(online) $=$ ISSN $2285-3642$ \\ ISSN-L = $2285-3642$ \\ Journal of Economic Development, Environment and People \\ Volume 7, Issue 2, 2018
}

URL: http://jedep.spiruharet.ro

e-mail: office jedep@spiruharet.ro

promotion of Tidung Island and considered it less effective. Although destination image has been one of the most important topic in the tourist literature, there has been lack of attention by researcher regarding the context of stopover destination image for long-aul international traveler (Pike and Kotsi, 2018)

In comparison, the result of the primary data sorting of recapitulation of the spread of questionnaires on tourists who are visiting Island Tidung. This GAP result will then be compared with GAP results on the assessment of potential tourist. This will determine satisfaction of tourists before and after a visit or tour on the island.

Table 3 indicates that the expectations of tourists to visit Tidung Island is quite high, it's just that the quality of governance of tourist destinations has not been optimal enough. This can be seen by the magnitude of GAP between perception and preference 2.07 and the perception index (2.41). The data can be interpreted in the form of a chart (Fig. 3).

Table 3. Perception and Preferences of Existing Tourists

\begin{tabular}{|c|c|c|c|c|c|}
\hline Variable & Indicator & $\begin{array}{l}\text { Perceptio } \\
\text { n }\end{array}$ & $\begin{array}{l}\text { Preferenc } \\
\text { e }\end{array}$ & $\begin{array}{l}\text { GAP } \\
\text { (Pe-Pr) }\end{array}$ & Tki \\
\hline \multirow[t]{4}{*}{ Product } & Quality of Tourist Site & 4 & 2 & 2 & 2 \\
\hline & Diversity of Attraction & 4 & 2 & 2 & 2 \\
\hline & Cleanliness & 5 & 2 & 3 & 2,5 \\
\hline & Queue Method & 4 & 1 & 3 & 4 \\
\hline \multirow[t]{2}{*}{ Promotion } & Media Quality & 5 & 3 & 2 & 1,67 \\
\hline & $\begin{array}{l}\text { Frequency of } \\
\text { promotion }\end{array}$ & 5 & 2 & 3 & 2,5 \\
\hline \multirow[t]{3}{*}{ Transportation } & Conveyance Quality & 4 & 2 & 2 & 2 \\
\hline & Frequency & 5 & 1 & 4 & 5 \\
\hline & Length of Travel & 4 & 2 & 2 & 2 \\
\hline \multirow[t]{4}{*}{ Price } & Food Prices & 2 & 3 & -1 & 0,67 \\
\hline & Accommodation Price & 2 & 4 & -2 & 0,5 \\
\hline & Mode Ticket Price & 5 & 2 & 3 & 2,5 \\
\hline & Rental Price & 5 & 2 & 3 & 2,5 \\
\hline \multirow[t]{2}{*}{ Services } & HR Quality & 4 & 3 & 1 & 1,3 \\
\hline & Quality Amenities & 5 & 1 & 4 & 5 \\
\hline & C-Line & 4,2 & 2,13 & 2,1 & 2,41 \\
\hline
\end{tabular}

Source; Primary data, 2017

Thus, it is seen that almost all the tourist indicators on Tidung Island are considered unsatisfactory, only at the indicator of the price of lodging and the price of food tourists is out of the expectation. This is because, in fact, tourists consider the price of food and lodging in Island Tidung relatively cheap. 

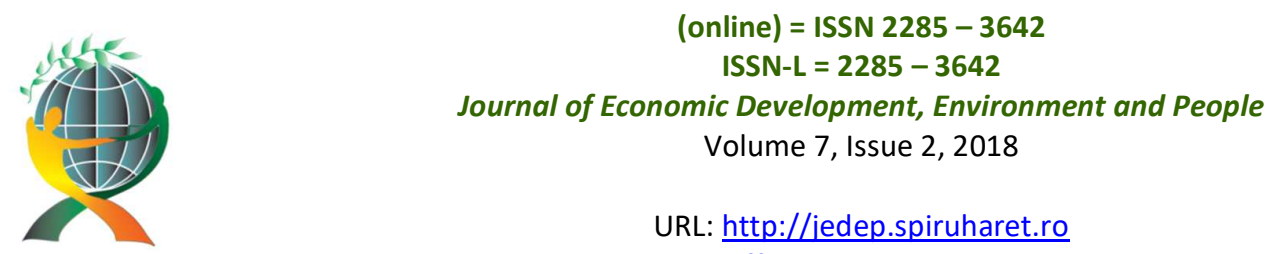

URL: http://jedep.spiruharet.ro

e-mail: office jedep@spiruharet.ro

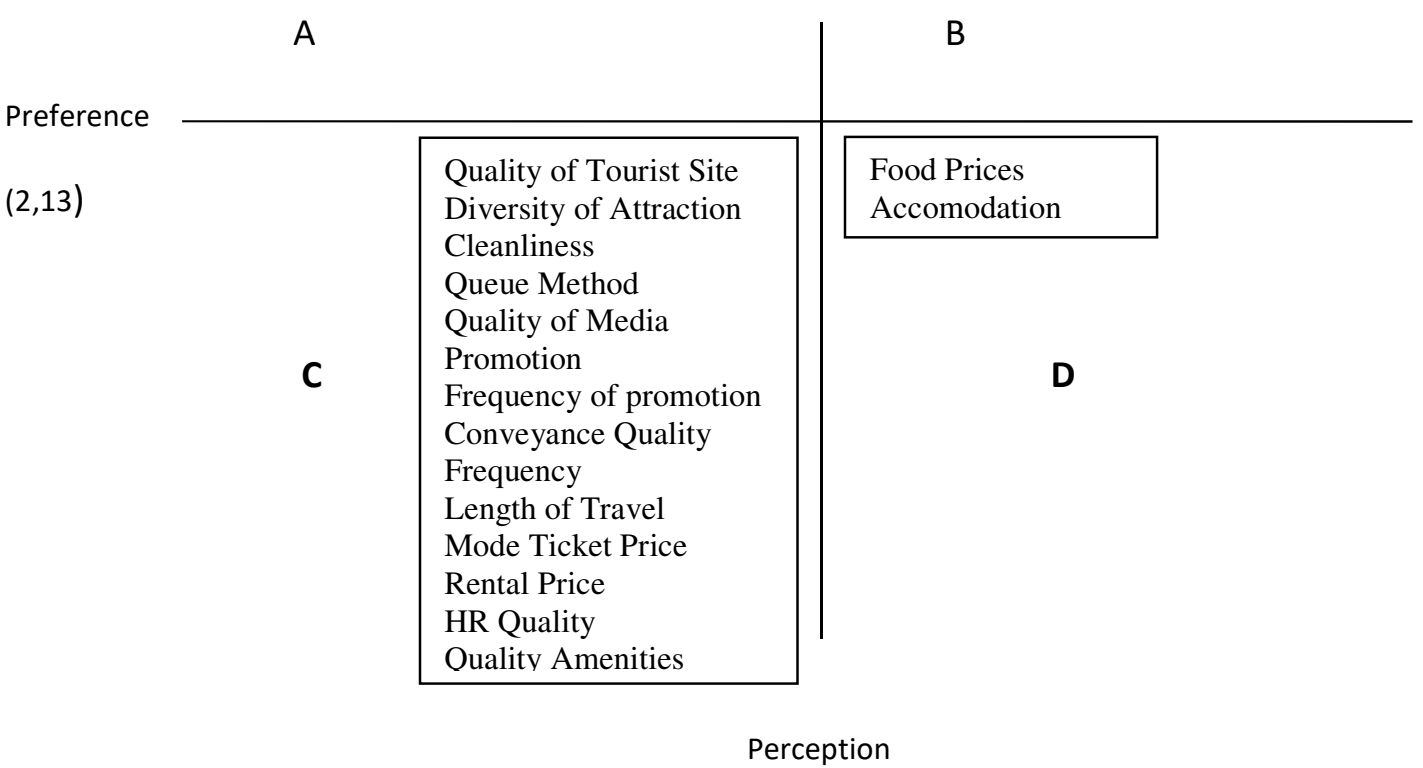

$(4,2)$

Fig 3. IPA Existing Tourists (Source; Primary data, 2017)

\section{Conclusion}

In the opinion of the people of Jakarta, Tidung Island tourist positioning is good enough. Because, the location of Tidung Island is relatively close to Jakarta. Tourism segment in Tidung Island is created for the middle-class tourists, so it makes Tidung Island as an alternative for the Jakarta residents. However, tourism management in Tidung Island has not been maximized. So, the tourists who come this time tend to "hit and run" or just come once. Need to improve the quality of tourism management in Tidung Island by improving the Quality of Tourist Site, Diversity of Attraction, Cleanliness, Queue Method, Quality of the Media Promotion, Frequency of Promotion, Conveyance Quality, Frequency, Length of Travel, Mode Ticket Price, Rental Price, HR Quality and Quality Amenities.

\section{References}

[1] Aprilia, C. 2008. Peranan Bidang Pemasaran Pariwisata Dinas Kepariwisataan Kota Bandung Dalam Mempromosikan Program Bandung Kota Kreatif. Tugas Akhir. Universitas Widyatama, Bandung.

[2] Anggraini, D. 2008. Analisis Potensi Wisata Bahari Di Kawasan Taman Nasional Kelslandan Seribu, Propinsi DKI Jakarta Dengan Pemetaan Recreation Oportunity Spectrum. Tesis. Institut Pertanian Bogor. Bogor.

[3] Choi, Miju. Lee, Jin-Soo. Seo, Ava J. 2018. Shopping Destination Competitiveness: Scale Development and Validation. Journal of Travel and Tourism Marketing. https://doi.org/10.1080/10548408.2018.1475276

[4] Methew, Paul V and Sreejesh S. 2017. Impact of Responsible Tourist on Destination Sustainability and Quality of Life of Cimmunity in Tourist Destination. Journal of Hospitality and Tourist Management, 3, 83-89. 


\author{
(online) $=$ ISSN $2285-3642$ \\ ISSN-L = $2285-3642$ \\ Journal of Economic Development, Environment and People \\ Volume 7, Issue 2, 2018 \\ URL: http://jedep.spiruharet.ro \\ e-mail: office jedep@spiruharet.ro
}

[5] Martens Hanno, Reiser, Dirk. 2017. Analysing the image of Abu Dhabi and Dubai as tourism destinations - The perception of first-time visitors from Germany. Tourism and Hospitality Research. https://doi.org/10.1177/1467358417690436

[6] Lyon, Andrew. Hunter-Jones, Philippa. Warnaby, Gary. 2017. Are We Any Closer to Sustainable Development? Listening to Activity Stakeholder Discourses of Tourism Development in The Waterberg Biosphere Reserve, South Africa. Tourism Management, 61, 234-247.

[7] Purnama. 2008. Efektifitas Strategi Pemasaran Produk Wisata Minat Khusus Goa Cerme, Bantul. Jurnal Siasat Bisnis. 12(3), 187-197.

[8] Pike, Steven and Kotsi, Filareti. 2018. Stopover Destination Image-Persections of Dubai, United Arab Emirates, Among Franch and Australian Traveler. Journal of Travel and Tourism Marketing, 1-15. https://doi.org/10.1080/10548408.2018.1476303

[9] Siregar, MA. 2004. Pengembangan Pariwisata Dalam Kontribusinya Untuk Penanggulangan Kemiskinan. Warta Pariwisata. 7(4), 29-41.

[10] Sari, YAM. 2009. Peranan Promosi Dan Pemasaran Dalam Meningkatkan Jumlah Wisatawan Di Objek Wisata Dayu Alam Sari. Laporan Penelitian. Universitas Sebelas Maret. Surakarta.

[11] Sumaryoto. (2016). The Influence of Regional Revenue on Government Invesment and Its Implication to The Regional Economic Growth. Journal of Applied Economic Science. 8(46). P.1552-1568.

[12] Untari, DT. 2016. The Potential Development of Betawi Culinary as an Ecotourism Product in Jakarta. Binus Business Review. 7(3), 277-282.

[13] Untari, Dhian Tyas. Avenzora, Ricky. Darusman, Dudung. Prihatno, Joko. 2017. Betawi Culinary; Sosio-Cultures Frame of Multi Communities In Jakarta. Advance Science Letters. 23 (9), 8519-8523

[14] Untari, Dhian Tyas. Avenzora, Ricky. Darusman, Dudung. Prihatno, Joko. 2017. Betawi Traditional Cuisines; Reflection the Native Culture of Jakarta (Formerly Known as Batavia). Journal of Economic Development Environment and People. 6(4), 64-76.

[15] Vanhove, N. 2005. The Economics of Tourism Destinations. Elsevier Butterworth Heineman, Oxford. 